\title{
Cultural paradiplomacy institutions and agenda \\ The case of Rio Grande do Sul, Brazil
}

\author{
Instituições e agenda de paradiplomacia cultural \\ O caso do Rio Grande do Sul
}

Instituciones y agenda de paradiplomacia cultural El caso de Rio Grande do Sul, Brasil

\begin{abstract}
This article aims to analise how the Brazilian State of Rio Grande do Sul (RS) projects its distinctive cultural identity internationally. It does so by identifying the cultural elements in the state's paradiplomacy from 1987 to 2014 through a sequence analysis including two elements: RS's paradiplomatic and cultural institutions; RS's paradiplomatic agenda. Three phases are identified in terms of space given to culture in the paradiplomacy institutional framework: expansion (1987-1994); retraction (19952010); expansion (2011-2014). The phases are slightly different in terms of agenda: will but lack of means (1987-1990); focus on other issues (1991-2010); construction of an incipient agenda (2011-2014). Also, the 2012 actions to structure cultural policy at federal and state level can be seen as a factor for the agenda expansion in the last phase. However, despite the discourse around the gaúcha identity being present within the state and country, the projection further afield remains weak. Generally, the multiple changes in institutional framework and agenda show that a long-term project has not been decided on. Thus, the resulting policies are highly dependent on each governor's vision.
\end{abstract} Keywords: Paradiplomacy. Culture. Rio Grande do Sul.

Resumo: O objetivo deste artigo é de avaliar como o Estado do Rio Grande do Sul (RS), Brasil, projeta internacionalmente a sua identidade cultural singular. Para tanto, ele busca identificar os elementos culturais na paradiplomacia do estado de 1987 a 2014 com uma análise de trajetória composta de dois elementos: as instituições paradiplomáticas e culturais do RS; a agenda paradiplomática do RS. São identificadas três fases em termos de espaço dado à cultura na estrutura paradiplomática: expansão (1987-1994); redução (1995-2010); expansão (2011-2014). As fases relativas à agenda são um pouco diferentes: ambição, mas falta de meios (1987-1990); foco em outras temáticas (1991-2010); construção de uma agenda incipiente (2011-2014). Além disso, as ações conduzidas em 2012 para estruturar as políticas culturais em nível federal e estadual podem ser vistas como um fator da expansão da agenda na última fase.

\footnotetext{
* Universidade de Brasília (UnB, Brasília, DF, Brasil).

author.biographic_data
}

Civitas, Porto Alegre, v. 18, n. 2, p. 351-375, May-Aug. 2018 
Entretanto, apesar do discurso ao redor da identidade gaúcha ser presente dentro do estado e em nível nacional, a projeção internacional dele é fraca. De maneira geral, as múltiplas mudanças na estrutura institucional e na agenda mostram que um projeto de longo prazo não foi estabelecido. Portanto, as políticas resultantes são altamente dependentes da visão de cada governador.

Palavras-chave: Paradiplomacia. Cultura. Rio Grande do Sul.

Resumen: El propósito de este artículo es de analizar cómo el Estado de Rio Grande do Sul (RS), Brasil, proyecta internacionalmente su identidad cultural. Con este objetivo, se busca identificar los elementos culturales de la paradiplomacia del estado de 1987 a 2014 mediante un análisis de su trayectoria, y en concreto de dos elementos: las instituciones paradiplomáticas y culturales de RS y la agenda paradiplomática de RS. Se identifican tres fases en términos de espacio dado a la cultura en la estructura paradiplomática: expansión (1987-1994); reducción (1995-2010); expansión (20112014). Las fases relativas a la agenda son un poco diferentes: ambición, pero falta de medios (1987-1990); enfoque en otros temas (1991-2010); construcción de una agenda incipiente (2011-2014). Además, las acciones llevadas a cabo a nivel federal y estatal para estructurar las políticas culturales pueden ser vistas como un factor de expansión de la agenda en la última fase. Sin embargo, pese a que el discurso sobre la identidad gaucha está presente dentro del estado y a nivel nacional, su proyección internacional es débil. De manera general, los múltiples cambios en la estructura institucional y en la agenda muestran que no se estableció un proyecto de largo plazo. Por lo tanto, las políticas resultantes son altamente dependientes de la visión de cada gobernador.

Palabras clave: Paradiplomacia. Cultura. Rio Grande do Sul.

\section{Introduction}

Both culture and paradiplomacy are themes which have entered the International Relations debate quite late: in the 1990s. Perhaps for this reason, they retain a rather peripheral position in this area of study, though their role in international relations has been increasingly studied over the past years. Generally, the literature on paradiplomacy remains predominantly European, focusing mostly on western cases and drawing theories from these specific contexts. Based on the acknowledgement of this scarcity of studies originating from other parts of the world and on a desire to go beyond the most clear cut empirical cases (Québec, the Basque Country, Flanders...), our aim is to make a contribution to the emerging Brazilian literature on the subject (Vigevani et al., 2004; Milani and Ribeiro, 2011; Bueno, 2012; Salomón and Nunes, 2007) studying a Brazilian empirical case. Focusing specifically on the intersection between paradiplomacy and culture - another emerging field of study in the country - this article aims to analyse the international cultural projection of the Brazilian state of Rio Grande do Sul. 
Specifically, the question around which this article is articulated is the following: Which cultural elements can be identified in Rio Grande do Sul's paradiplomacy? To which extent can we say that this sub-national actor has developed a cultural identity which is projected internationally? To answer this question, we will conduct an in-depth sequence analysis (Pierson, 2004) of the evolution of the state's cultural paradiplomatic apparatus and agenda. The period chosen to conduct this analysis is 1987-2014, starting with the creation of the first paradiplomatic apparatus in Rio Grande do Sul (from now on referred to as RS) and ending in 2014, which corresponds to the end of the last completed state governor mandate. The choice of RS stems from the strong cultural identity which exists in this state, which makes it an interesting case study in terms of political strategy and desire to project this identity internationally.

\section{The study of paradiplomacy and its cultural aspects}

\section{The rise of paradiplomacy}

Having emerged in the 1980 s, the phenomenon of the transfer of jurisdiction from central governments to sub-national governments and of the growing independence and international activity of the latter solidified as a field of academic study in the 1990s. As a practice and as a field of study, this phenomenon is based on the idea that the ideal decision-making entity is the city, or that decisions should be made as locally as possible (Moreno, 2007, p. 37).

First labeled as "paradiplomacy" by Panayotis Soldatos (1990) as an abbreviation of "parallel diplomacy", the phenomenon was later given various other denominations. The most well-known are "micro-diplomacy" (Duchacek et. al., 1988; Duchacek, 1990) and 'foreign policy of non-central governments' (Aldecoa and Keating, 1999), but others such as multi-level diplomacy, city diplomacy, internationalisation of cities, decentralised cooperation and international actions of local governments have also been used (Gely, 2016).

These multiple denominations show that the field is diverse and suffers from a certain lack of unity. This is the result of two factors. Firstly, the field of paradiplomacy is profoundly multidisciplinary. Furthermore, most publications on the subject are based on empirical studies and the heterogeneity of the cases makes it difficult to establish a general theory (Gely, 2016).

The most accepted and all-encompassing definition is certainly the one given by Prieto (2004, p. 251; own translation): 


\begin{abstract}
Paradiplomacy can be defined as the involvement of subnational governments in international relations, through the establishment of contacts with foreign entities, which can be formal and informal, permanent or temporary ('ad hoc'), with public or private entities, with the aim of reaching socio-economic results, as well as any external aspect within their jurisdiction.
\end{abstract}

Based on this general understanding of paradiplomacy, we will define our specific object of study: cultural paradiplomacy.

\title{
Cultural diplomacy: conceptual dimensions
}

Cultural activities, goods and services, as recognised in the Unesco's 2005 Convention on the Protection and Promotion of the Diversity of Cultural Expressions, have a double nature: economic, by their commercial value; and symbolic, by the identitarian aspects which they bear (Unesco, 2005). Because of this double nature, they are powerful foreign policy and diplomacy tools in a globalised world (Stoica and Horga, 2016).

Generally speaking, cultural diplomacy can be defined "in its most basic terms as an international actor's attempt to manage the international environment by facilitating cultural transmission across an international boundary" (Cull, 2009, p. 53). However, it is useful to dig further and make a certain number of additions to this general definition.

Firstly, based on the multidimensional definition of culture mentioned above, cultural diplomacy can be seen as relating to two different realms: the economic and the sociopolitical realms. In this sense, international cultural projection can be "either about effecting or constraining particular outcomes, or about transforming or constituting the identity of the actors and the issues themselves" (Singh, 2010, p. 4).

Secondly, there are some divergences in terms of definition of what constitutes cultural diplomacy, making it necessary for us to position ourselves in relation to this debate. A first distinction which is made is between international cultural relations and cultural diplomacy. Whilst international cultural relations include all cultural activities which take place beyond national borders, cultural diplomacy is restricted to international cultural activities with some form of involvement by public institutions (Bélanger, 1994).

Beyond this first distinction, some authors such as J. M. Mitchell (1986, apud Bélanger, 1994) distinguish two types of cultural diplomacy. The first is led directly by public institutions and as such, is developed according to foreign policy aims. The other is led by private or para-governmental organisations 
and even though it is inserted within the general foreign policy framework, it corresponds to these organisations' aims.

In line with Robert Frank (2012), the understanding of cultural diplomacy which underlies this article is that there are multiple interactions between the public and private sectors in this field: the cultural diplomacy developed by public agents depends on the intellectual and artistic production of the civil society; whilst private agents involved in international cultural activities often rely on help from the state to develop their projects. In this sense, a more detailed and practical definition of cultural diplomacy is given by Lessa (2012) in the following sentence: "all the actions formulated, oriented, led and funded, totally or in part, by the state, whether by its agents or by non-governmental partners" (own translation). According to this vision, the two crucial elements to define cultural diplomacy are the following: international cultural activities and involvement of the state.

Working with a wide definition of cultural diplomacy which includes actors from civil society brings us close to the notion of New Public Diplomacy which could also be referred to as "collaborative diplomacy" (Riordan, 2005, p. 1). The latter is characterised by the involvement, along with governmental agents, of non-governmental agents which operate through more agile and flexible networks (Riordan, 2005). This type of diplomacy aims to stimulate dialogue based on the international exchange of ideas, cultures and people (De Lima Júnior, 2015) in an increasingly informed and connected post-modern world. Thus, in New Public Diplomacy, cultural activities are given more importance than in traditional diplomacy: "In cultural relations as much as in the new public diplomacy, the accent is increasingly on engaging with foreign audiences rather than selling messages, on mutuality and the establishment of stable relationships instead of mere policy-driven campaigns" (Melissen, 2005, p. 21-22).

\section{Defining cultural paradiplomacy}

Cultural diplomacy, generally studied at the national level, can exist according to the same logic at the sub-national level. Paradiplomacy, in all its different forms, is a "multifunctional vehicle for the promotion of interests and identity" (Lecours, 2008, p. 5) and as such, can be used to pursue the same purposes as the cultural diplomacy of a nation.

Paradiplomacy is a multifactorial phenomenon, most often stemming from a feeling of disconnection of a community from the central state, for economic or for identitarian reasons (and often both) (Sarquís, 2013, apud Dávila and Silva, 2016). Amongst paradiplomacy scholars, some - generally 
those with a constructivist approach - have devoted time to its cultural, identitarian, psychological or historical aspects (Dávila; Silva, 2016). Follows a brief summary of the predominant thoughts on and classifications of cultural and identitarian aspects of paradiplomacy.

Aldecoa and Keating (1999) distinguish three categories of paradiplomatic aims: the economic, the political and the cultural aims. The latter encompass objectives such as cultural preservation, the establishment of cultural links with other countries or regions and activities contributing to the international projection of a community's culture.

Stéphane Paquin (2004a) also established a classification of paradiplomatic activity. His first category, classic paradiplomacy, corresponds to actions which enable the international projection of a political vision. The second, protodiplomacy, refers to actions aimed at securing independence. Finally, identity paradiplomacy corresponds to the construction or reinforcing of a minority nation within a multinational state, without pursuing the objective of independence. The purpose of this last category of paradiplomacy is to secure abroad resources which are scarce internally and to be recognised internationally. According to Paquin, nationalism is an undervalued variable within the study of paradiplomacy, though it is not the main one. For him, economic aims prevail in explaining the development of paradiplomatic strategies by sub-national actors (Paquin, 2004b).

Lecours distinguishes three layers of paradiplomacy. First, the economic layer, which according to him is strictly focused on the attraction of foreign capital and as such is not intertwined with any political or cultural issues. Second, he distinguishes the layer concerned with cooperation, which can be cultural, technical, educational or of another nature. This layer involves a more multidimensional approach. Finally, the third layer is linked to political considerations. Often, though not always, this implies the projection by the community in question of an identity which is different from the one projected by the national state or a desire for political independence. These three layers can be combined in an actor's paradiplomacy and they are non-exclusive (Lecours, 2008).

Contrary to what most theorists of paradiplomacy see as the most important variable to determine the level of international projection of regions - federalism -, Lecours and Moreno (2001) see substate or stateless nationalism as the most important factor to qualitatively account for this phenomenon. Though not a necessary condition for the development of regional paradiplomacy, nationalism gives the region a reason to develop three elements which are also fundamental to the development of paradiplomacy: 
identity/nation building; political-territorial mobilisation; and promotion of regional interests.

They outline a number of processes which contribute to the development of identity construction or consolidation (the first element), in varying measures depending on the cases: cultural change, institutional development, socioeconomic transformations and political context/competition. Beyond these four factors, they highlight the crucial importance of the discursive aspect: the region presenting itself as an entity (Lecours and Moreno, 2001).

The third element, the definition and promotion of regional interests, generally encompasses two dimensions: the development of an ideological/ political discourse; and the promotion and politicisation of a cultural distinctiveness. According to the authors, "cultural defence and promotion tend to be the most important issues of paradiplomacy because they are central to its underlying force, nationalism. Paradiplomacy extends the domestic struggles of nationalist movements for cultural preservation into international politics" (Lecours and Moreno, 2001, p. 3).

The following table aims to summarise visually the three aforementioned classifications:

Table 1. Classifications of paradiplomatic activity

\begin{tabular}{lll}
\hline $\begin{array}{l}\text { Aldecoa; Keating } \\
\text { (1999) }\end{array}$ & $\begin{array}{l}\text { Paquin } \\
(\mathbf{2 0 0 4 a}, \mathbf{2 0 0 4 b})\end{array}$ & $\begin{array}{l}\text { Lecours } \\
\mathbf{( 2 0 0 8 )}\end{array}$ \\
\hline $\begin{array}{l}\text { 1. Economic aim } \\
\text { 2. Political aim }\end{array}$ & 1. Classic paradiplomacy & 1. Economic layer \\
3. Cultural aim & 2. Protodiplomacy & 2. Cooperation layer \\
$\begin{array}{l}\text { Classification based } \\
\text { on aims }\end{array}$ & $\begin{array}{l}\text { Classification based } \\
\text { on aims }\end{array}$ & $\begin{array}{l}\text { Classification based on } \\
\text { categories of issues }\end{array}$ \\
\hline
\end{tabular}

Table elaborated by the author based on: Dávila and Silva, 2016; Lecours, 2008; Paquin 2004a, 2004 b.

Distinguishing themselves from these three authors who analise paradiplomacy either in terms of aims or categories of issues, Dávila and Silva (2016) develop an analysis of paradiplomacy based on the motivations of the actors. According to them, a wide range of reasons can lead to the development of paradiplomatic actions by a subnational government, such as the desire to project an image internationally, local development or identitarian considerations. For them, the identitarian aspect of paradiplomatic action is not to be found in the final aims of the actors but in the incentives which push them to develop the action. "What is most common is for the identitarian element 
to justify any form of rapprochement between the parts and the decision making it implies; this way, in the cases in which identity doesn't constitute the incentive, it is at least used to disguise and legitimise it" (Dávila and Silva, 2016, p. 94, own translation).

Finally, Prieto (2010) argues that as is the case with diplomacy, paradiplomacy has two dimensions: instrumental and symbolic. The first corresponds to objectives such as the attraction of foreign investment, the promotion of the country or the access to multilateral forums; whilst the second corresponds to objectives such as cultural and political promotion. We would argue that, on the basis of cultural activities' double nature (economic and symbolic) mentioned previously, cultural paradiplomacy can be considered both instrumental and symbolic.

As a conclusion, one can see that it is very difficult to categorise cultural paradiplomacy on the basis of existing categories. As argued by Singh (2010), it relates both to the economic realm and the socio-political realm as it has an instrumental as well as a symbolic dimension (Prieto, 2010). We would argue that culture can be found in the three layers of paradiplomacy identified by Lecours (2008). As highlighted by Aldecoa and Keating (1999) and Paquin (2004a, 2004b), it can be an aim. Furthermore, it can sometimes constitute an incentive (Dávila and Silva, 2016) and most often, though not always, it has links with nationalism (Lecours and Moreno, 2001).

\section{Methodology}

On the basis of this statement, the perspective adopted here is of seeing culture as a paradiplomatic tool, including in the notion of cultural paradiplomacy all cultural actions of an international nature which receive some form of support from a subnational government. This definition allows us to consider jointly international actions corresponding to all types of aims and possibly constituting a motivation, as long as the tool which is used is culture. It also avoids going into considerations around nationalism, which is a debated notion for the empirical case studied here. Furthermore, it acknowledges the incipient nature of cultural policies and paradiplomacy in Brazil, which implies that the use of culture most often is not the result of a structured strategy based on long term goals and partnerships, but are the result of ad hoc projects.

This analysis will be based on the framework in two parts used by Salomón and Nunes (2007) in their study of the paradiplomacies of the state of Rio Grande do Sul and the city of Porto Alegre: 1. Analysis of the institutional framework for paradiplomacy; 2. Analysis of the paradiplomatic agenda. It 
will be adapted to the specifics of cultural paradiplomacy, with an attempt to identify an additional element seen as crucial by Lecours and Moreno (2001) in identity construction: the presence of a discursive aspect.

\section{Cultural paradiplomacy: institutional context in Brazil}

\section{The institutional context of paradiplomacy}

Brazil's 1988 constitution, which prevails currently, does not institutionalise paradiplomacy. A number of specific responsibilities are transferred to subnational governments and there is no constitutional rule forbidding them to establish international activities (Milani and Ribeiro, 2011). Furthermore, the central state recognises a number of decentralised cooperation networks, such as Mercocidades within the Mercosul. However, officially, all international action remains a prerogative of the central state: "Art. 21. Is a prerogative of the Federal State: I - to maintain relations with foreign States and take part in international organisations" (Brasil, 1988, art. 21, own translation) and thus Brazilian paradiplomacy is maintained within "unlawful practices" ("situações irregulares" Vigevani, 2004, p. 29). Additionally, the Brazilian system concentrates financial resources in the Federal State, making it difficult for subnational governments to increase their remit and actions (Branco, 2007).

\section{The institutional context of cultural policies}

Though the existence of cultural policies in Brazil dates back from the 1930s (Oliveira, 2012), the cooperation between the different federal entities in terms of cultural policy was only officially established in 2012 through a modification of the Brazilian constitution ${ }^{1}$ which initiated the National Cultural System. This system, "organised in a collaborative manner, in a decentralised and participative way, establishes a process of joint management and promotion of cultural public policies" (Brasil, 1988, art. 216-A, § 1, own translation).

Amongst others, this system included the following principles: "IV - cooperation between federal bodies, public and private cultural agents"; "V - integration and interaction in the carrying out of policies, programmes, projects and actions"; "VIII - autonomy of the federal bodies and of civil society institutions"; "XI - coordinated and agreed decentralisation of management, resources and actions"; "XII - progressive increase of the public budgets dedicated to culture" (Brasil, 1988, art. 216-A, §1, own translation).

\footnotetext{
${ }^{1}$ With the PEC 71/2012 which added article 216-A to the Federal Constitution.
} 
It also determines that "The States, the Federal District and the Municipalities will organise their own cultural systems in dedicated laws" (Brasil, 1988, art. 216-A, §4, own translation). Generally, it officialised the importance of culture as a public policy and the independence of different public bodies in implementing their own policies and projects in that field. As a consequence of this law and with the help of the Ministry of Culture, a number of Brazilian states, ${ }^{2}$ including Rio Grande do Sul, developed state cultural plans (planos estaduais de cultura).

\section{Case study: the cultural paradiplomacy of the state of Rio Grande do Sul}

\section{Institutional framework for cultural paradiplomacy}

\section{Paradiplomacy framework: 1987-1994}

In terms of international relations, the Rio Grande do Sul state (from now on referred to as RS) was pioneer. In 1987, it was the second Brazilian state to establish an administrative framework for the state's international actions (Bueno, 2012; Ferreira, 2015b; Salomón and Nunes, 2007).

It was under Pedro Simon's (1987-1990, PMDB [Partido do Movimento Democrático do Brasil]) leadership in RS that the Seai (Special Secretariat for International Affairs [Secretaria Especial de Assuntos Internacionais]) was created. It had the following attributions: advise the governor on relations with other countries, most importantly those of the La Plata basin, and with international organisations; supervise and guide state government administrations in terms of international relations; raise funds and attract investments; and provide consultancy for the private sector. It was subdivided into the following departments: 1 - International cooperation; 2 - Private investments; 3 - Latin American integration, which itself was subdivided into a section dedicated to integration and another one to cultural cooperation (Salomón and Nunes, 2007). One can therefore see that from the start, RS' international strategy included cultural preoccupations in its very framework, before the Mercosul (and the Mercosul Cultural) had even been created.

Alceu de Deus Collares (1991-1994, PDT [Partido Democrático Trabalhista]) maintained and developed the Seai. In the International Cooperation Department were created different Technical Cooperation sections: International Cooperation; Cooperation with Developing Countries;

${ }^{2}$ Acre, Amapá, Bahia, Ceará, Distrito Federal, Goiás, Mato Grosso, Mato Grosso do Sul, Paraíba, Rio de Janeiro, Rio Grande do Norte, Rio Grande do Sul, Rondônia, Roraima, Santa Catarina, Sergipe, Tocantins. 
Cooperation with Partner-States. The Business Department was given an International Events section and a Business Cooperation and Promotion section. Finally, the Latin American integration department was separated into an Information and Documentation section; a Border Issues section; a Cultural Integration section and a Latin-American Studies section (Salomón and Nunes, 2007). Still, we can see that cultural issues had a dedicated section and that there was a strong focus on Latin America.

\section{Paradiplomacy framework: 1995-2010}

Antônio Britto (1995-1998, PMDB) closed down the Seai and created the Sedai (Development and International Affairs Secretariat [Secretaria do Desenvolvimento e dos Assuntos Internacionais]) which fused the Secretariats for International Affairs and for Industry and Business. This new secretariat no longer dealt with international issues in general: it focused on the inclusion of RS into international markets, with a focus on Mercosul (Salomón and Nunes, 2007). Initially, the Sedai had two departments: Latin American integration; International cooperation and business. In 1996, they were fused into a sole department called Department for International Affairs and Latin American Integration [Departamento de Assuntos Internacionais e de Integração Latino Americana - DIN], itself subdivided into the following five sections: 1 - Latin American Integration; 2 - International Cooperation; 3 - International Business; 4 - International Business Networks; 5 - Consular Relations. Also, in 1995, the Itamaraty [Brazilian Ministry of Foreign Affairs] opened a regional office in RS, as it did in other Brazilian states.

Olívio Dutra (1999-2002, PT [Partido dos Trabalhadores]) kept the structure established by his predecessor, but changed the five sections to two: 1 - International Business; 2 - International Affairs. Regional integration came back onto the agenda with the creation of a Special Office for Mercosul affairs, but it was extinguished after less than a year (Salomón and Nunes, 2007). One can see that in these last two administrations, the administrative framework shifted to focus largely on economic issues. Though the Latin-American region remained a priority, it was more in terms of trade than in terms of integration.

Under Germano Rigotto's mandate (2003-2006, PMDB), it is interesting to note that the opposition between the party under power in RS and in the federal state was reversed, with the PMDB now leading RS and the election of president Lula (PT) at the head of the federal state (Ferreira, 2015b).

Rigotto maintained the division of the Department for International Affairs and Latin American Integration into the two sections created by his predecessor. However, under allegations of excessive debt, the action was 
restrained back to economic affairs and the number of teams within the sections was reduced. The first was composed of the International Fairs sector and the Exporter Room, a service in support of exporters. The second section was subdivided into International Cooperation; Consular Relations; International Governmental missions; and Latin American Affairs (Salomón and Nunes, 2007). Out of six programmes carried out during this period, only one is not strictly focused on trade: the Integrations and International Cooperation Programme ${ }^{3}$ (Ferreira, 2015b).

Under Yeda Crusius' mandate (2007-2010, PSDB [Partido da Social Democracia Brasileira]), the state's framework for international actions made an even clearer turn towards economic actions. The Sedai was subdivided into four departments: Department for International affairs, which integrated a few responsibilities in terms of international political activities, along with economic ones; and the Departments for business development; for the promotion of investments; and the Sales Board whose attributions were all strictly economic. ${ }^{4}$

\section{Paradiplomacy framework: 2011-2014}

With the arrival of Tarso Genro (2011-2014, PT), significant changes were made to the paradiplomacy institutional framework of RS. The Sedai was closed down and the state's international relations were envisaged in a horizontal way for the first time, without a secretariat dedicated to international relations. Each secretariat was given responsibility for international actions within its remit, with support from the newly created Acri (Advisory Board for Cooperation and International Relations [Assessoria de Cooperação e Relações Internacionais]), which was attached to the Governor's cabinet. The Acri's role was to ensure the coherence of international actions led by the secretariats, on the basis of state government guidelines. It also got involved in all international activities involving the Governor as well as all the international receptions organised by the secretariats, with the intention of increasing homogeneity. The innovative framework proved quite fruitful and had the added benefit of enabling civil servants from different areas to develop international relations skills (Ferreira, 2015a).

\footnotetext{
${ }^{3}$ The complete list of programmes is as follows: Capacitação para a Competitividade Empresarial (PCCE); Cooperação Empresarial e Inovação (PCI); Atração de Investimentos (Proain); Acesso ao Crédito (Peac); Exporta/RS; Programa de Integração e Cooperação Internacional (PIC).

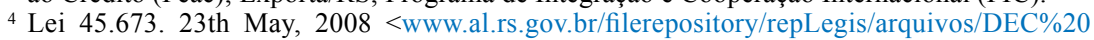
45.673.pdf> (6th Dec. 2016).
} 


\section{Brief summary of the cultural framework}

In order to understand and draw a full picture of the international projection of RS's culture as part of its paradiplomacy, it is important to briefly expose the context for cultural production within the state. The first state cultural institutions were created in the 1950s, amongst which it is worth mentioning the Cultural Division and the Institute for Traditions and Folklore. The 1980s were a decade in which the protection and promotion of regional traditions rose considerably, along with cultural industries linked to the gaúcho ${ }^{5}$ way of life. It is also in the 1980s that the first programmes aiming to highlight the Italian and German influences were created within the state (Pinto, 2011).

During the Simon administration, the Cultural Development Council [Conselho de Desenvolvimento da Cultura-Codec] was created. Its main aim was to develop a cultural policy which would enable the closer integration of the La Plata basin countries, along with the promotion of the gaúcho identity and of international cultural exchange (Pinto, 2011). One can identify a coherence with Simon's general international relations framework, which aimed to include culture and focused on the La Plata basin region.

In 1996, a 'Lei de Incentivo à Cultura' ${ }^{6}$ was created for the state of RS with, amongst its various objectives: value the way of life and cultural production of RS; promote the exchange and circulation of cultural activities and products from RS to other Brazilian states and internationally (Pinto, 2011). However, in contradiction with this last aim, the amounts given to cultural projects via this mechanism are to be spent within the state of RS, which restricts their use for cultural paradiplomacy actions.

It is worth mentioning that the Secretariat for Tourism's strategic plan for 2007-2010 focuses on gaúcho culture as one of the focal points of the state's touristic planning. This valuing of culture within the touristic policies was structured around two lines: 1- Promotion of the European heritage of the state; 2- Actions around the valuing of gaúcho culture (Pinto, 2011).

Finally, as mentioned previously, RS, along with various other states, created a state culture plan in 2012 following the general structuring of the cultural sector by the federal state in 2012 with the elaboration of the National Cultural Plan.

\footnotetext{
${ }^{5}$ Inhabitant of the State of Rio Grande do Sul or person carrying the culture associated to the state.

${ }^{6}$ System which funds cultural actions through tax credits.
} 


\section{Summary of the evolution of RS' framework for cultural paradiplomacy}

Follows a table summarising the evolution of the institutional framework for the implementation of international actions by the state, highlighting the institutional bodies through which international cultural actions could be implemented:

Table 2. Evolution of RS's paradiplomatic and cultural institutional framework

\begin{tabular}{|c|c|c|c|c|}
\hline Mandate & Governor & Party & Institutional structure/IR & Institutional structure/culture \\
\hline $1987-1990$ & Pedro Simon & PMDB & $\begin{array}{l}\text { Seai (Special Secretariat for } \\
\text { International Affairs) } \\
\text { 1. International cooperation } \\
\text { 2. Private investments } \\
\text { 3. Latin American integration } \\
\text { integration; cultural cooperation }\end{array}$ & $\begin{array}{l}\frac{\text { Cultural Development Council }}{(\text { Codec })} \\
\text { - integration of the La Plata } \\
\text { basin countries } \\
\text { - promotion of the gaúcho identity } \\
\text { - international cultural exchange }\end{array}$ \\
\hline 1991-1994 & $\begin{array}{l}\text { Alceu de Deus } \\
\text { Collares }\end{array}$ & PDT & $\begin{array}{l}\text { Seai } \\
\text { 1. International cooperation } \\
\text { department } \\
\text { technical international } \\
\text { cooperation; technical } \\
\text { cooperation with developing } \\
\text { countries; technical } \\
\text { cooperation with partner-states } \\
\text { 2. Business Department } \\
\text { international events; business } \\
\text { cooperation and promotion } \\
\text { 3. Latin American integration } \\
\text { department } \\
\text { information \& documentation; } \\
\text { border issues; cultural } \\
\text { integration; Latin-American } \\
\text { studies }\end{array}$ & \\
\hline 1995-1998 & Antônio Britto & PMDB & $\begin{array}{l}{[1995-1996]} \\
\frac{\text { Sedai (Development and }}{\text { International Affairs Secretariat) }} \\
\text { 1. Latin American integration } \\
\text { 2. International cooperation and } \\
\text { business } \\
\text { [1996-1999] } \\
\text { Sedai } \\
\text { Department for International } \\
\text { Affairs and Latin American } \\
\text { Integration } \\
\text { Latin American integration; } \\
\text { international cooperation; } \\
\text { international business; } \\
\text { international business networks; } \\
\text { consular relations }\end{array}$ & $\begin{array}{l}\text { State Lei de Incentivo à Cultura } \\
\underline{(1996)}\end{array}$ \\
\hline
\end{tabular}


Table 2 (continued)

\begin{tabular}{|c|c|c|c|c|}
\hline Mandate & Governor & Party & Institutional structure/IR & Institutional structure/culture \\
\hline 1999-2002 & Olívio Dutra & PT & $\begin{array}{l}\underline{\text { Sedai }} \\
\text { Department for International } \\
\text { Affairs and Latin American } \\
\text { Integration } \\
\text { 1. International Business } \\
\text { 2. International Affairs } \\
\text { \# Special Office for Mercosul } \\
\quad \text { Affairs }^{(1)}\end{array}$ & \\
\hline $2003-2006$ & $\begin{array}{l}\text { Germano } \\
\text { Rigotto }\end{array}$ & PMDB & $\begin{array}{l}\text { Sedai } \\
\text { Department for International } \\
\text { Affairs and Latin American } \\
\text { Integration } \\
\text { 1. International Business } \\
\quad \text { International Fairs sector; } \\
\text { Exporter Room } \\
\text { 2. International Affairs } \\
\text { International Cooperation; } \\
\text { Consular Relations; } \\
\text { International Governmental } \\
\text { missions; Latin American Affairs }\end{array}$ & \\
\hline $2007-2010$ & Yeda Crusius & PSDB & $\begin{array}{l}\frac{\text { Sedai }}{\text { 1. Department for International }} \\
\text { affairs } \\
\text { 2. Department for business } \\
\text { development } \\
\text { 3. Department for the promotion } \\
\text { of investments } \\
\text { 4. Sales Board }\end{array}$ & \\
\hline 2011-2014 & Tarso Genro & PT & $\begin{array}{l}\text { Acri (Advisory Board for } \\
\text { Cooperation and International } \\
\underline{\text { Relations) }}\end{array}$ & $\underline{\text { State Cultural Plan (2012) }}$ \\
\hline
\end{tabular}

(1) Closed down in 2000 .

Table elaborated by the author based on: Ferreira, 2015a; 2015b; Salomón and Nunes, 2007; Pinto, 2011.

Analysing the evolution of the institutional framework for paradiplomacy in RS brings us to a certain number of conclusions. Firstly, the framework for international actions changed a lot throughout the different mandates which were analysed here, showing that the state government is still looking for a functioning long-term formula (Salomón and Nunes, 2007). Secondly, it shows us how international actions in RS are highly dependent on the interests, vision and actions of each governor.

Finally, our sequence analysis brings us to distinguish three phases. In the first phase, going from 1987 to 1995, RS' paradiplomacy was carried out by the Seai, which gave significant institutional space to cultural questions 
(not entering into considerations around effectivity). Drawing parallels with the institutionalisation of the cultural field in RS shows that a discourse around the use of culture for integration with La Plata basin neighbours was also present. In the second phase, going from 1996 to 2011, the span of the state's paradiplomacy was reduced to focus more and more on economic issues, setting cultural ones aside. The third phase started in 2011 and takes us to the end of our period of study, 2014. This phase was characterised by institutional innovation with a new framework which left space for international actions in all sectors of the state's activity, including cultural issues.

\section{Cultural paradiplomacy agenda}

\section{The question of nationalism}

In line with Lecours' argument that the most important element influencing the existence of paradiplomacy of an identitarian nature is nationalism, it is important to consider this question for our case. Rio Grande do Sul, with its past marked by events such as the Farroupilha Revolution (1835-1845) and the Federalist Revolution (1893-1895) and with its remains of contemporary regionalist discourse from part of the population, is a region of Brazil where the question of the characterisation and projection of an identity is posed quite strongly.

The gaúchos, in general terms, have a strong cultural identity linked to historical, cultural and territorial aspects which have created in them a specific relationship to the local and the national: a distancing from the national and the Brazilian 'other' - and an exacerbated attachment to the local (Luvizotto, 2003). Further than this, there is debate as to whether this distinct identity can be classified as regionalism with serious separatist ambitions. According to Matsumoto (2011), the formation of the Brazilian state happened without a segmentation comparable to the ones which can be found in states such as Spain or Canada. Though very diverse, its population presents an identitarian homogeneity. Milani and Ribeiro (2011, p. 32) also conclude their study of the paradiplomacy of Brazilian cities saying that they "do not call ethno-national belonging into question. Emancipation exists, but only partially, and not irrespective of the federative pact and the contradictory (but sustained) role of the nation-state in Brazil". According to Matsumoto (2011), there aren't Brazilian cases of paradiplomacy which are based on identity arguments and in RS, this phenomenon is marginal. However, despite this initial diagnosis, when testing the causal relation between geographic location and the development of paradiplomatic activity, Matsumoto found that the localisation of a municipality within the RS state had a positive correlation 
with the existence of an international relations institutional framework within city councils. Therefore, even though the question of the significance of the separatist movement in RS is debatable, one can see that the distinctive and strong identity which exists in the region is a variable which influences paradiplomacy and is therefore interesting to be taken into account.

\section{Cultural paradiplomacy agenda 1987-1990:}

\section{a will, but reduced means}

During the Simon administration, the main motivation of the state government was integration with Southern Cone neighbours, from 1987 and even more so after the creation of the Mercosul in 1991. Most actions were focused on political negotiations, development of borders and of infrastructure and cultural and academic exchange (Nunes, 2005). Follows a list of some of the actions which were developed at that time and which illustrate this focus: creation of the State Commission for the Integrated Development of the Border [Comissão Estadual para o Desenvolvimento Integrado da Fronteira - Cedif]; of the Mercosul steering committee [Coordenadoria do Mercosul]; of the Border Committees [Comitês de Fronteira]; of the Codesul-Crecenea Litoral [Conselho de Desenvolvimento e Integração Sul (Brazil); Comissão Regional de Comércio Exterior do Nordeste e Litoral (Argentina)] governor forum; and of ten Thematic Integration Groups [Grupos de Integração Temática - GIT] of which one was dedicated to culture (Salomón and Nunes, 2007). Alongside initiatives at the border with Argentina and within the South Cone, actions were developed in the USA, Spain and Japan. In the latter, the twinning programme with the Shiga province included a specific programme dedicated to culture and is the longest standing and most prolific programme of the sort to date. Despite these ambitions, the downside was the nonexistence of a dedicated budget or staff within the Seai, which limited effectiveness (Nunes, 2005).

\section{Cultural diplomacy agenda 1991-2010:}

\section{an absence of political and cultural planning}

During the Collares administration, there wasn't a particular focus on international activities but the structure of the Seai was maintained and slightly amplified. The focus was on commercial promotion, promotion of international investments and economic integration within the Mercosul. Academic cooperation programmes were abandoned and the Seai remained without a dedicated budget and unqualified staff (Nunes, 2005). Generally, what can be said about this period is that there were wide ambitions, which included cultural aspects - mostly within the Cone Sul and twin city partnerships, and 
more during Simon's mandate than during Collares's - but limited means, which reduced the institution's effectiveness.

The change from the creation of the Sedai under Britto's mandate was an increase in the institution's capacities for action, allied with a reduced scope (Salomón and Nunes, 2007), the new organisation being almost entirely focused on economic issues (Nunes, 2005). Various forums and city twinning programmes established during the Simon administration were abandoned. Less actions can therefore be highlighted in terms of cultural paradiplomacy from the time when the Sedai was created, except to say that during the Dutra administration, despite the organisation's still pregnant focus on economic issues, the institution's remit was slightly widened to include some actions around technical and scientific cooperation (Ferreira, 2015b).

During the Rigotto and Crusius administrations, the focus of RS in terms of international actions was mainly economic. One cannot say that they were exclusively economic as some relations were maintained with foreign states and with international organisations, but the lack of an international political plan is visible (Ferreira, 2015a, p. 9) and the secretariat's preoccupation with maintaining the level of international projection of RS was minimal (Ferreira, 2015b).

One initiative which is worth mentioning is the signature during the Crusius administration of an agreement with the Italian region of Friuli Venezia Giulia in terms of technical-educational cooperation, based on past immigration of Italians from that region to RS (Ferreira, 2015a). Secondly, the Codesul, of which Crusius was president in 2007-2008, was reactivated during this period. In 2008, during the tenth meeting of Codesul-Crenecea Litoral governors, the Porto Alegre Charter [Carta de Porto Alegre] was signed. In it, governors reaffirmed their common interest in developing the integration of the region in various fields, including cultural and touristic integration with the objective of "strengthening the concept of South American citizenship" (Ferreira, 2015a, p. 11). However, one can say that the few cooperation actions which were developed during that time were based on sporadic interests rather than a significant component within a plan for the international relations of the state (Ferreira, 2015a).

\section{Cultural diplomacy agenda 2011-2014: emergence of a cultural discourse}

The arrival of Tarso Genro at the head of the RS state in 2011 marked the beginning of a new phase. Besides the change in terms of institutional framework mentioned previously, we can identify three changes in terms of agenda. 
Firstly, there was a diversification of the areas of involvement of the state. Based on the fact that economic paradiplomacy had been consolidated by various previous governors, the Genro administration established a new framework in which all international actions would now be developed incorporating three aspects: economic, political-institutional and cultural (Núñez, 2014). Cultural cooperation was put forward as a way of making international relations about integration between populations, being a "fundamental dimension in order to establish relationships and identitarian bonds with the people of the countries with which RS is in relation" (Núñez, 2014, p. 51).

In 2012, a cooperation mission was organised in France, with the president and the Minister of Higher Education and Research. Exchanges were established in the following areas: public policies, education, environment, culture, science and technology. Existing cooperation agreements were developed, with Manitoba (Canada); with Shiga (Japan) in the cultural and environmental areas; and with Chungnam-Do (South Korea) in the science and technology area (Ferreira, 2015a).

A second element which can be identified is the intention of projecting an image of RS internationally (Ferreira, 2015a). This is clear in Genro's campaign slogan, "Rio Grande do Sul, do Brasil e do Mundo" (Núñez, 2014, p. 50), which expresses clearly a desire, at least rhetoric, to place the state within a larger international framework. According to Núñez, this change of perspective also corresponded to the desire to follow, at the subnational level, the new international protagonist role which Brazil was taking on at the time.

The third element which was developed during Genro's mandate was cooperation and integration within the South Cone region. A cultural, educational and social exchange programme was established with Uruguay. Following a cooperation project with Argentina, the Mercosul Museum of Human Rights was created in Porto Alegre with the additional support of Uruguay. Programmes for the development of the borders were also intensified (Ferreira, 2015a).

According to Ramos (2014), this diversification of areas of action is relative. She argues that economic relations remained the principal action front in Genro's administration; that actions in other fields were led in the same countries as in previous governments (mainly the South Cone countries) and that economic interests can be found behind actions in other areas. Though we agree with her diagnosis, we have to disagree with her conclusions. Though economic relations may have remained pregnant within RS's international actions, the existence of some (natural) continuity in terms of economic 
paradiplomacy and in terms of partner countries does not nullify the actions which were led in other fields. Our diagnosis is that along with some elements of continuity in terms of economic paradiplomacy and partner countries, some incursions were made into new areas of action, amongst which the cultural field; a discourse emerged in terms of the international projection of the state; and initiatives around regional cooperation and integration were resumed following various mandates nearly exclusively focused on economic relations.

\section{Summary of the evolution of RS's cultural paradiplomatic agenda}

Follows a table summarising the evolution of RS's international relations agenda:

Table 3. Evolution of RS's paradiplomatic agenda

\begin{tabular}{|c|c|c|c|c|}
\hline Mandate & Governor & Party & IR Priorities & Main partners \\
\hline $1987-1990$ & Pedro Simon & PMDB & $\begin{array}{l}\text { - Regional integration } \\
\text { - Border and infrastructure } \\
\text { development } \\
\text { - Cultural and academic exchange }\end{array}$ & $\begin{array}{l}\text { South Cone countries } \\
\text { USA } \\
\text { Spain } \\
\text { Japan }\end{array}$ \\
\hline 1991-1994 & $\begin{array}{l}\text { Alceu de Deus } \\
\text { Collares }\end{array}$ & PDT & $\begin{array}{l}\text { - Economic relations } \\
\text { - Regional integration }\end{array}$ & South Cone countries \\
\hline 1995-1998 & Antônio Britto & PMDB & $\begin{array}{l}\text { - Economic relations } \\
\text { - Regional integration }\end{array}$ & $\begin{array}{l}\text { South Cone countries } \\
\text { Japan } \\
\text { Canada } \\
\text { USA }\end{array}$ \\
\hline 1999-2002 & Olívio Dutra & $\mathrm{PT}$ & $\begin{array}{l}\text { - Economic relations } \\
\text { - Regional integration } \\
\text { - Technical cooperation }\end{array}$ & $\begin{array}{l}\text { South Cone countries } \\
\text { Canada } \\
\text { European countries }\end{array}$ \\
\hline 2003-2006 & $\begin{array}{l}\text { Germano } \\
\text { Rigotto }\end{array}$ & PMDB & $\begin{array}{l}\text { - Economic relations } \\
\text { - Regional integration }\end{array}$ & $\begin{array}{l}\text { South Cone countries } \\
\text { Other partners: ad hoc }\end{array}$ \\
\hline $2007-2010$ & Yeda Crusius & PSDB & $\begin{array}{l}\text { - Economic relations } \\
\text { - Regional integration }\end{array}$ & $\begin{array}{l}\text { South Cone countries } \\
\text { Italy } \\
\text { Other partners: ad hoc }\end{array}$ \\
\hline 2011-2014 & Tarso Genro & PT & $\begin{array}{l}\text { - Economic relations (agriculture) } \\
\text { - Regional integration } \\
\text { - Political-institutional relations } \\
\text { - Cultural relations } \\
\text { - Relations with Latin American } \\
\text { countries }\end{array}$ & $\begin{array}{l}\text { South Cone countries } \\
\text { Cuba } \\
\text { Manitoba (Canada) } \\
\text { Shiga (Japan) } \\
\text { Chungnam- Do (South Korea) }\end{array}$ \\
\hline
\end{tabular}

Table elaborated by the author based on: Nunes, 2005; Salomón and Nunes, 2007; Ferreira, 2015a; 2015b; Núñez, 2014.

From this historical analysis of RS's international relations agenda, we can identify an absence of long-term planning, actions being developed in an ad-hoc way by each government (Nunes, 2005) and corresponding more to 
government development policies than to a proper state development policy (Ferreira, 2015a).

Going beyond this statement, we can identify three phases in terms of the existence or non-existence of a cultural aspect within the paradiplomacy of the state. The first one (1987-1990) is characterised by an ambitious agenda which included some cultural aspects, mostly focused on Latin America, but the lack of financial and staffing structure meant that actions didn't reach the level of ambitions projected. The second phase (1991-2010) is characterised by a focus on economic relations, which meant that culture was virtually absent from RS's paradiplomacy. The third phase (2011-2014) is characterised by a diversification of the paradiplomatic agenda which brought back cultural questions and by the will to project a stronger image of RS internationally. The presence of a discursive element around the international cultural projection of the RS state can only be identified in the last phase.

\section{Conclusions}

As a general conclusion to our study based on the sequence analysis of RS's use of culture as a paradiplomatic tool, we want to make the following points.

In terms of space given to culture within the institutional framework dedicated to paradiplomacy, we have identified a phase of expansion (19871994), followed by a phase of retraction (1995-2010), followed by another phase of expansion (2011-2015).

In terms of agenda, the dividing of the phases is slightly different: a phase of will tampered by a lack of means (1987-1990), followed by a phase of focus on questions other than culture (1991-2010), followed by a phase of construction of an incipient cultural paradiplomatic agenda and discourse (2011-2015).

We have seen that although a discursive element around the gaúcha identity is definitely present in RS at least since the 1980s, this identity is present mostly within the state and projected in the rest of the country. The projection of this identity further afield is not very strong, probably due to a lack of institutional structure supporting this.

Finally, we can say that the emergence of a state projection of a cultural nature in the last governor mandate studied here was probably due both to factors of a regional nature identified previously and to factors of a national nature. In 2012, the establishment of a national framework for culture pushed many states, amongst which RS, to establish their own cultural frameworks and to perceive the importance of culture as a public policy. 
The conclusion of the mandate of RS' last governor José Ivo Sartori in 2018 will tell us whether these initial measures in terms of cultural paradiplomacy marked the real development of long-term policies or whether they constituted ones of the many oscillations in RS' tentative cultural paradiplomacy initiatives.

\section{Acknowledgments}

The author wishes to thank Estevão Chaves de Rezende Martins (University of Brasília, Brazil), Eduardo Viola (University of Brasília, Brazil), Demétrio Gaspari Cirne de Toledo (Federal University of ABC, Brazil), as well as anonymous reviewers for their comments on previous versions of this article. A previous version of this paper was presented at the $6^{\text {th }}$ Congress of the Brazilian International Studies Association (Abri), PUC Minas, Belo Horizonte, 25-28 July 2017. This research was conducted thanks to support from the National Council for Scientific and Technological Development (CNPq).

\section{References}

ALDECOA, Francisco; KEATING, Michael [eds.]. Paradiplomacy in action: the foreign relations of subnational governments. London: Frank Cast. 1999.

BÉLANGER, Louis. La diplomatie culturelle des provinces canadiennes. Études Internationales, v. 25, n. 3, p. 421-452, 1994.

BRANCO, Álvaro Chagas Castelo. A paradiplomacia como forma de inserção internacional de unidades subnacionais. Prismas, v. 4, n, 1, p. 48-67, $2007<10.5102 /$ prismas.v4i1.216>.

BRASIL. Constituição da República Federativa do Brasil. Brasília, 5 de outubro de 1988 <www.planalto.gov.br/ccivil_03/Constituicao/Constituicao.htm> (26 Nov. 2016).

BUENO, Ironildes. Paradiplomacia econômica: trajetórias e tendências da atuação internacional dos governos estaduais do Brasil e dos Estados Unidos. Brasília: Editora Verdana, 2012.

CULL, Nicholas J. Public diplomacy: lessons from the past: a report for the Public Diplomacy Group of the Foreign and Commonwealth Office. London. Figueroa Press, 2009.

DÁVILA, Victorino Morales; SILVA, Carlos Manuel Reyes. Identidades compartidas: la centralidad de los lazos culturales como motor paradiplomático. Desafios, v. 28, n. 1, p. 79-12, 2016.

DE LIMA JÚNIOR, Antônio Ferreira. O papel da diplomacia pública nas relações internacionais contemporâneas. 5th National Congress of the Brazilian International Relations Association (Abri), Belo Horizonte, 29-31 July 2015. 
DUCHACEK, Ivo. Perforated sovereignties: towards a typology of new actors in international relations. In: H. J. Michelmann; P. Soldatos [eds]. Federalism and international relations: the role of subnational units. Oxford: Clarenton Press, 1990. p. 1-33.

DUCHACEK, Ivo; LATOUCHE, Daniel; STEVENSON, Garth [eds.]. Perforated sovereignties and international relations: trans-sovereign contacts of subnational governments. New York: Greenwood Press. 1988.

FERREIRA, Bruno Guedes. A paradiplomacia no Rio Grande do Sul (2007-2014): um comparativo das ações externas em diferentes posições político partidárias. 1st Political Science International Seminar, Universidade Federal do Rio Grande do Sul, Porto Alegre, 9-11 Sept. 2015a.

FERREIRA, Bruno Guedes. Atores públicos subnacionais e policia externa brasileira: a paradiplomacia no Rio Grande do Sul (2007-2014). 2015b. Dissertação de mestrado (Ciências sociais) - Faculdade de Filosofia e Ciências Humanas, Pontifícia Universidade Católica do Rio Grande do Sul, Porto Alegre.

FRANK, Robert. Culture et relations internationales: les diplomaties culturelles. In: Robert Frank [org.]. Pour l'histoire des Relations Internationales. Paris: Presses Universitaires de France, 2012. p. 317-386.

GELY, Mary. Hacia una mejor conceptualización teórica de la proyección internacional de los gobiernos locales. In: Sergio González Miranda; Noé Cornago Prieto; Cristian Ovando Santana [eds.]. Relaciones transfronterizas y paradiplomacia en América Latina: aspectos teóricos y estudio de casos. Santiago de Chile: RiL Editores, 2016. p. 161-176.

LECOURS, André. Political issues of paradiplomacy: lessons from the developed world. Netherlands Institute of International Relations 'Clingendael', $2008<w w w$. clingendael.nl/sites/default/files/20081217_cdsp_diplomacy_paper_paradiplomacy. pdf> (3 Oct. 2016).

LECOURS, André; MORENO, Luis. Paradiplomacy and stateless nations: a reference to the Basque Country. Conference The Institutional Accommodation of Diversity, Saint Marc sur le Richelieu, Québec, September 20-22, 2001. Working paper.

LESSA, Mônica Leite. Cultura e política externa: o lugar do Brasil na cena internacional (2003-2010). In: Hugo Rogelio Suppo; Mônica Leite Lessa (eds.). A quarta dimensão da relações internacionais: a dimensão cultural. Rio de Janeiro: Contra Capa, 2012. p. 169-192.

LUVIZOTTO, Caroline Kraus. Etnicidade e separatismo no Rio Grande do Sul. 2003. Dissertação de mestrado (Ciências sociais) - Faculdade de Filosofia e Ciências, Universidade Estadual Paulista "Júlio de Mesquita Filho", Marília.

MATSUMOTO, Carlos Eduardo Higa. As determinantes locais da paradiplomacia: o caso dos municípios brasileiros. 2011. Dissertação de mestrado (Relações Internacionais) - Instituto de Relações Internacionais, Universidade de Brasília, Brasília.

MELISSEN, Jan [ed.]. The new public diplomacy: soft power in international relations. London: Palgrave Macmillan, $2005<10.1057 / 9780230554931>$. 
MILANI, Carlos R. S; RIBEIRO, Maria Clotilde Meirelles. International relations and the paradiplomacy of Brazilian cities: crafting the concept of local international management. $B A R$, v. 8, n. 1, p. 21-36, $2011<10.1590 /$ S1807-76922011000100003>.

MITCHELL, J.M. International Cultural Relations, London: Allen and Unwin, 1986.

MORENO, Luis. Identités duales et nations sans État (la Question Moreno). Revue Internationale de Politique Comparée, v. 144, n. 4, p. 497-513, 2007 <www.uclouvain. be/cps/ucl/doc/spri/documents/RIPC_2007_14-4_B.pdf> (2 Dec. 2016).

NUNES, Carmen Juçara da Silva. A paradiplomacia no Brasil: o caso do Rio Grande do Sul. 2005. Dissertação (Mestrado em Relações Internacionais) - Programa de Pósgraduação em Relações Internacionais, Universidade Federal do Rio Grande do Sul, Porto Alegre.

NÚÑ̃Z, Tarson. A experiência da assessoria de cooperação e relações internacionais do Governo do Estado do Rio Grande do Sul. In: Jacques Marcovitch; Pedro B. A. Dallari [eds.]. Relações internacionais de âmbito subnacional: a experiência de estados e municípios no Brasil. São Paulo: Instituto de Relações Internacionais da Universidade de São Paulo, 2014. p. 48-56.

OLIVEIRA, Paulo Augusto Almeida de. Novo paradigma de política cultural brasileira: as políticas públicas de governo e de estado. 8o Encontro de Estudos Multidisciplinares em Cultura (Enecult). Salvador, Bahia, Brasil. 8-10 Aug. 2012.

PAQUIN, Stéphane. Paradiplomatie et relations internationales: théorie des stratégies internationales des régions face à la mondialisation. Bruxelles: Presses Interuniversitaires Européennes. 2004a.

PAQUIN, Stéphane. La paradiplomatie identitaire: le Québec, la Catalogne et la Flandre en relations internationales. Politique et Sociétés, v. 23, n. 2-3, p. 203-237, 2004b.

PIERSON, Paul. Politics in time: history, institutions, and social analysis. Princeton: Princeton University Press, 2004.

PINTO, Muriel. A construção da identidade missionária no Rio Grande do Sul e as polícias culturais no sul do Brasil. 2011. Dissertação de mestrado (Desenvolvimento Regional) - Programa de Pós-Graduação em Desenvolvimento Regional, Universidade de Santa Cruz do Sul - Unisc, Santa Cruz do Sul.

PRIETO, Noé Cornago. O outro lado do novo regionalismo pós-soviético e da ÁsiaPacífico: a diplomacia federativa além das fronteiras do mundo ocidental. In: Tullo Vigevani; Luiz Eduardo Wanderley; M. Inês Barreto; P. Mariano [eds]. A dimensão subnacional e as relações internacionais. São Paulo: Educ, 2004. p. 251-282.

PRIETO, Noé Cornago. La descentralización como elemento de innovación diplomatica: aproximación a sus causas estructurales y lógicas de acción. In: L. Maira (ed.). La política internacional subnacional en América Latina. Buenos Aires: El Zorzal, 2010. p. 107-134.

RAMOS, Fabielly Bellagamba. A paradiplomacia no Estado do Rio Grande do Sul: análise dos três últimos mandatos governamentais (2003-2014). 2014. TCC (Graduação em Administração) - Administração Pública e Social, Universidade Federal do Rio Grande do Sul, Porto Alegre. 
RIORDAN, Shaun. La nueva diplomacia. Foreign Policy Edición Española. n. 7, p. 22-31, 2005.

SALOMÓN, Mónica; NUNES, Carmen. A ação externa dos governos subnacionais no Brasil: os casos do Rio Grande do Sul e de Porto Alegre. Um estudo comparativo de dois tipos de atores mistos. Contexto Internacional, v. 29, n. 1, p. 99-147, 2007.

SARQUIS, David. Fundamentos teóricos para la reflexión en torno a la paradiplomacia. In: Zidane Zeraoui (eds.). Teoría y práctica de la paradiplomacia. Monterrey, México: Montiel \& Soriano Editores, 2013. p. 45-92.

SINGH, J. P. International cultural policies and power. Houndmills: Palgrave Macmillan, 2010.

SOLDATOS, Panayotis. An explanatory framework for the study of federal states as foreign policy actors. In: H. J. Michelmann; P. Soldatos [eds.]. Federalism and international relations: the role of subnational units. Oxford: Clarenton Press. 1990. p. 34-53.

STOICA, Alina; HORGA, Ioan. Culture and paradiplomatic identity: instruments in sustaining EU policies. In: Alina Stoica; Ioan Horga; Maria Manuela Tavares Ribeiro. Culture and paradiplomatic identity: instruments in sustaining EU policies. Newcastle Upon Tyne: Cambridge Scholars Publishing. 2016. p. 2-9.

UNESCO. Convention on the Protection and Promotion of the Diversity of Cultural Expressions. Paris: UNESCO, 2005<http://unesdoc.unesco.org/ images/0022/002253/225383E.pdf> (26 Nov. 2016).

VIGEVANI, Tullo. El marco jurídico e institucional para la gestión internacional de los actores subnacionales gubernamentales em Brasil. Integración \& Comércio, n.21, p. 27-46, 2004.

VIGEVANI, Tullo; WANDERLEY, Luiz Eduardo W.; BARRETO, Maria Inês; MARIANO, Marcelo Passini (eds.) A dimensão subnacional e as relações internacionais. São Paulo: Educ, 2004.

Received: 23 Oct. 2017

Approved: 26 Mar. 2018

Corresponding author:

Solène Marié

UnB - Instituto de Relações Internacionais

Campus Universitário Darcy Ribeiro - Asa Norte

70910-900 Brasília, DF, Brasil

SOLĖNE MARIÉ <solene.marie@gmail.com>

Doutoranda em relações internacionais pelo Instituto de Relações Internacionais da Universidade de Brasília (UnB, Brasília, DF, Brasil).

ORCID: https://orcid.org/0000-0001-6688-6439 